\title{
Community Group Networking on the Community-based Adaptation Measure in Tapak Village, Semarang Coastal Area
}

\author{
Bintang Septiarani ${ }^{*}$ and Wiwandari Handayani ${ }^{2}$ \\ Department of Civil and Planning, Vocational School, Diponegoro University, Indonesia \\ Department of Urban and Regional Planning, Faculty of Engineering, Diponegoro University, Indonesia
}

Received: 2018-11-17

Accepted: 2020-02-24

Keywords:
Semarang;
Community-based Adaptation;
Coastal;
Climate change

Correspondent email:

bintang.septiarani18@pwk.undip.ac.id

\begin{abstract}
The north coast of Central Java is one of the most vulnerable regions to climate change in Indonesia. Various activity in coastal area also leads to the growing of informal sector that closely related to the growing number of poor people in coastal area. Therefore, the loss of livelihood triggers the awareness of stakeholder to help people through Community-based Adaptation (CBA) in Semarang coastal area. This paper aims to elaborate on the importance of networking aspect in CBA that works in Semarang Coastal Area. Scope area of this research is Tapak Village which regarded as a pilot area of CBA implementation in Semarang. Stakeholders mapping and social network analysis was used to visualizing the community interaction in their adaptation measures. The purposive sample in interviewing CBA stakeholders is used to support the stakeholder analysis using Gephi 0.9 software. The finding shows that the existence of networks between the community and the relevant stakeholders such as NGO and local government also became one of the supporting factors for the sustainability of community-based adaptation approach in coastal areas of Semarang City.
\end{abstract}

\section{Introduction}

Adaptation effort has become the global major concern besides mitigation since the 4th assessment of IPCC (Intergovernmental Panel on Climate Change). The approach formerly made as top-down intervention by government to address physical vulnerability then lead also to address social vulnerability through the bottom-up approach. To enforce the bottom-up approach, National Government of Indonesia started to work with RAN-API (Rencana Aksi NasionalAdaptasi Perubahan Iklim) or National Action Plan on Climate Change Adaptation which encourages every local government in city level to make their own policy regarding with adaptation to climate change. CBA can be seen as a tailor-made approach that can increase people adaptive capacity because local people are more knowledgeable of their local situation (Feola \& Nunes, 2014; Marshall, Park, Howden, Dowd, \& Jakku, 2013). Hence, this approach is a promising measure that can increase local adaptation and also conserving their area in facing climate change impact. In Indonesia, CBA has been considered as a new approach that more suitable to local condition rather than a classical approach that tend to be more top-down (Archer et al., 2014).

In particular, many efforts have been done since the first CBA approach implemented in Indonesia. Semarang City, for instance, has become one of the recommendation cities in conducting their adaptation to climate change because of its initiative in Community-based Adaptation (CBA) process in 2009. The early approach of CBA in Semarang started since 2009 with the scoping community, and hazard and vulnerability assessment which aimed to increase people resilience by enhancing not only physical aspect but also the socio-economic and institutional aspects.

Semarang City is a coastal city located in the northern coast of Java Island. This coastal city in Indonesia is a major city and functioned as main trading and industrial center in Central Java Province, As become the main economic hub in Central Java, Semarang also facing serious problem in coastal inundation (as so-called Rob). The impact of Rob lead to the losses of physical and non-physical aspect of community (Buchori, Sugiri, et al., 2018; Marfai \& King, 2008a, 2008b). Structural measures has been taken by the government (Marfai \& King, 2008a) and community (Buchori, Pramitasari, Sugiri, Maryono, \& Basuki, 2018) but seems to be inadequate (Marfai \& King, 2008a) meanwhile, the migration is not an option for community (Handayani \& Kumalasari, 2015) due to community preferences to adapt (Buchori, Pramitasari, et al., 2018).

Tapak village located in Tugurejo district is one of the coastal regions in Semarang City which affected by tidal inundation (Marfai et al., 2008). Tapak is located at $110020^{\prime 2} 22^{\prime \prime} \mathrm{E}-110020^{\prime} 43^{\prime \prime} \mathrm{E}$ and $6057^{\prime} 16^{\prime \prime} \mathrm{S}-6059^{\prime} 10^{\prime \prime} \mathrm{S}$ with the total area 545.06 hectares and most of their area are fish pond (Semarang Statistical Bureau, 2017). Since 2010, a community in the coastal area of Tapak Village, Semarang City has planted more than 50.000 mangrove plants through several programs conducted in collaboration with other institutions from the government (environmental agency or $\mathrm{BLH}$, Marine and coastal agency or DKP), NGO, and the 


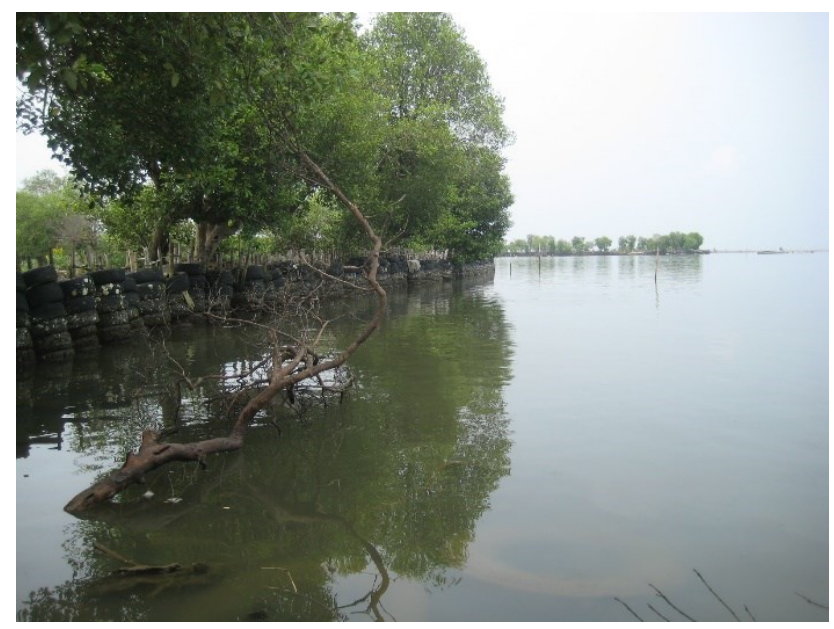

Figure 1. Coastline in Tapak that Already Protected with Mangroves

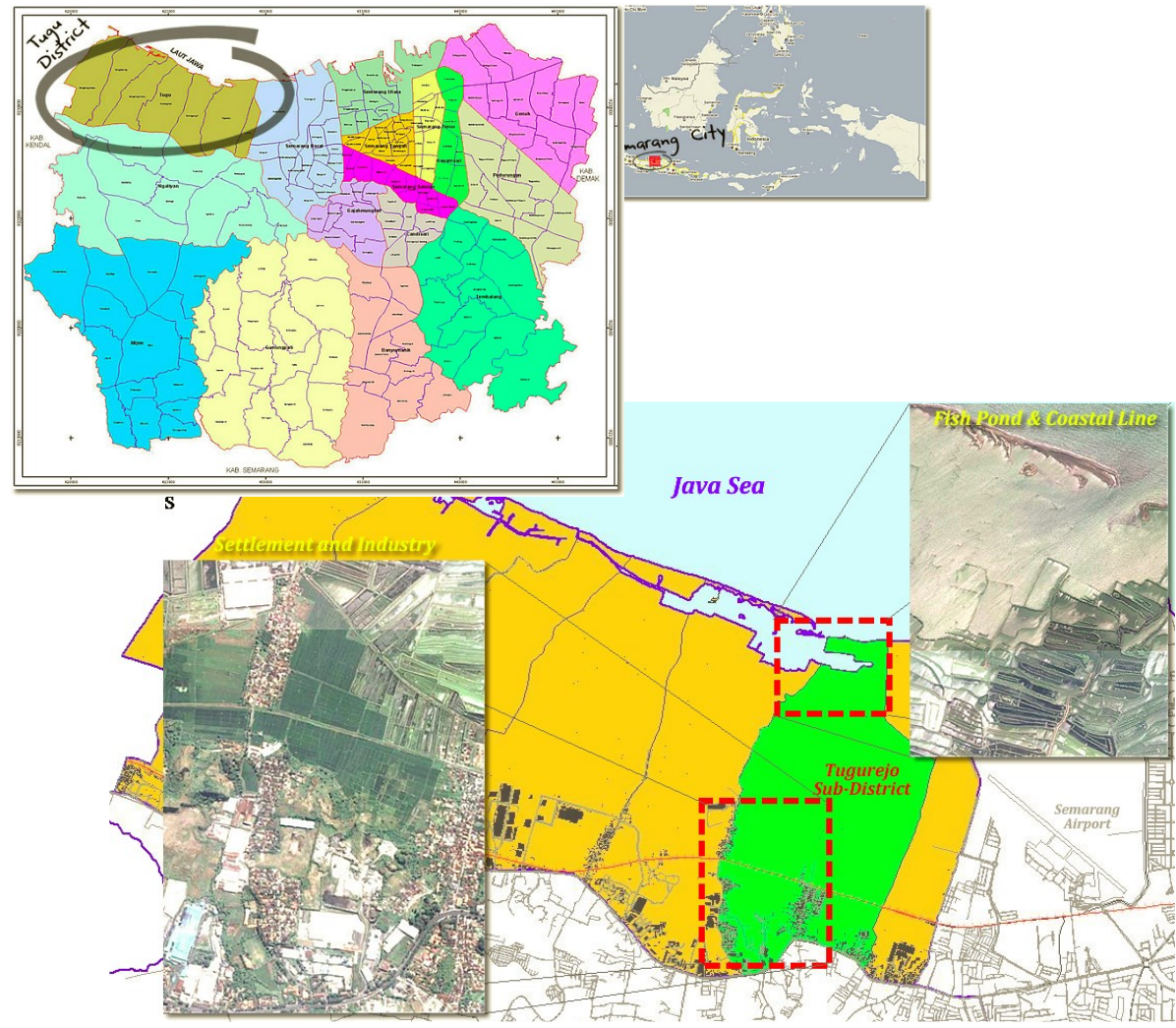

Figure 2. Prenjak Tapak Village location

private sector. It was recorded by Semarang Environmental Agency in 2015, the mangroves planting efforts done by the community has increased the coverage of mangrove forest in Tapak Village coastal area by more than 70\% in 2015 (from 18,63 ha in 2009 to 29,61 ha in 2015) (Bintari Foundation, 2016). The success of Tapak Village in conserving their environment has inspired other nearby villages. Hence, Tapak Village has become the "role model" of CBA in Semarang.

Although CBA is a local approach, the sustainability of this process depends on the engagement of various stakeholder including government, the private sector, academia and NGO (Feola \& Nunes, 2014; King, 2014). As many stakeholders involved in the CBA, it can become the challenge and opportunity for the development of CBA itself.
Thus the effort that conducted as the collaboration activity might wider community networking in sustaining their CBA. However, different resources management by different stakeholder can cause an overlapped activity that in the end will not be effective for the development of CBA itself.

The network formed by local actors could significantly support the development process in their area (Seyfang and Longhurst, 2013 in Feola \& Nunes, 2014). In addition, previous research on the case study of how cities respond to adaptation to climate change has drawn attention to the vital role of networks and partnerships in the calculation of efforts at the local level on adaptation to climate change in urban areas (Bulkeley et al, 2009; CAP, 2007; Tanner et al 2009; Wilson, 2006 in Carter et al., 2014). 
This paper aims to elaborate on the importance of networking aspect in CBA that works in Semarang Coastal Area. Generating adaptation strategies with communities and other local stakeholders increase the chance for sustainability of the process (Feola \& Nunes, 2014) because communities develop a strong sense of ownership and their priorities are met (Feola \& Nunes, 2014; King, 2014). Embedding new knowledge and understanding into existing community structures expands and strengthens those structures as well as institutional mechanisms (King, 2014). Rashid and Khan (2013) also suggested that CBA should be people centered, process oriented, community led, knowledge oriented, empowerment focused and accountability driven.

Some case studies demonstrate that there is no single model of good practice for CBA projects (King, 2014). The climatic, environmental, social, economic, and political context surrounding a community determines the design, implementation and possible outcomes of CBA processes and activities because this approach is more tailor-made based on the local condition. However, networking with other local or global actors, including other grassroots innovations, can significantly support the process of niche building (Seyfang and Longhurst, 2013 in Feola \& Nunes, 2014). The result of networking analysis shows that the community depends on community group to get funding, advice/guidance from other stakeholders in CBA network. The study conducted by identifying the stakeholders involved in CBA at Tapak Village and networking by a community group which becomes the factor that influences the sustainability of CBA. Hence, the presence of community group is important for the sustainability of the CBA practice in Semarang. Community group like Prenjak in Tapak Village has become the example of a community group that exists in the midst of sustaining CBA effort in Semarang coastal area. Prenjak networking can be considered as the factor that greatly influences their sustainability.

\section{The Methods}

To understand the importance of networking for CBA, this study tries to identify all the stakeholders that involved in CBA through the stakeholder mapping process. The stakeholders mapping is also used to identify the roles of stakeholder in Semarang coastal area. After mapping the stakeholders, social network analysis was used to visualize the connection and how each stakeholder interact within the network. Data obtained for this analysis is from interview and observation during January - February 2016.

Stakeholder Mapping
Stakeholder mapping is conducted to identify and classifies stakeholder based on their level of interest and involvement. This analysis aims to understand the CBA by identifying the key actors - or stakeholders - in the CBA process and assessing their respective interest (and involvement) in that system. Stakeholder and their involvement on CBA are identified through the interview. The first initiated stakeholder were already identified, however through the interview, there were identified that there is also private sector that have connection in the CBA. This step is conducted to understand how stakeholder are connected to each other in the CBA and become the input for social network analysis. The interview is conducted to the representatives/key person of community group, NGO, government institution and academia/research group regarding their connection to $\mathrm{CBA}$ in order to identify the type of interaction they have during the CBA process. The engagement of each stakeholder in $\mathrm{CBA}$ is various based on their interest and institute. Hence, this step aimed to understand not only the network of stakeholder but also what kind of interaction (Flow of information; the funding; informal support/advice/guidance) they made through the network.

\section{Social Network Analysis}

Social Network analysis can be used to visualize the connection between stakeholders in CBA and can be used as a tool to assess and express the pattern of connection (Kate, Keener, Finucane, Brewington, \& Nunn-crichton, 2015; Scott, 2000). To visualize the network within the stakeholder that involved in CBA, software Gephi 0.9 is used to calculate and visualize the connection in this analysis. Data of connection/interaction is obtained by the interview based on each stakeholder interaction and marked as " 1 " and " 0 ". " 1 " shows that there is a direct interaction meanwhile " 0 " shows there is no direct interaction between stakeholders. The " 1 " obtained when there is interaction from stakeholder listed in the row to stakeholder listed in the column from the matrix. The matrix used is a square case-by-case matrix by John Scott (2000). In the case-by-case matrix, both row and column represent the cases, and the individual cells show whether or not particular pairs of individuals and shows the actual relations or ties among the agents (Scott, 2000). Filling the matrix with actual data obtained from interviews are essential in this step because it will be an input for the social network analysis. In this study, the cases in the matrix are represented by the stakeholder that involved in CBA in both study area.

After filling the data, matrix are transformed and

Table 1. Case-by-case Matrix By John Scott

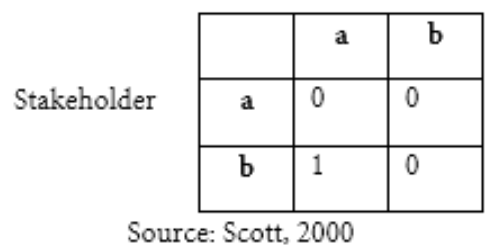

Source: Scott, 2000 
processed using another tool to visualize the connection. In this model, to analyze the network between those stakeholders, connection (edge) between stakeholders (nodes) are identified and divided based on their relation. For this CBA network analysis, researcher used the directed relation between nodes to analyze the relationship between stakeholders. Directed relation means that the interaction between nodes is made from one to another node with the certain direction (Scott, 2000). This aimed to understand not only the network of stakeholder but also what kind of interaction they made through the network. The network analysis conducted using software Gephi version 0.9 as a tool to visualize the network in both CBA.

\section{Result and Discussion}

The result from identifying stakeholder by the interview show that community in Tapak Village is identified as the most affected by resilience development. Not only the community but also the community group is affected by the climate change impact. Through the interview, there are 20 stakeholders identified in the coastal conservation activity in Tapak Village CBA.

\section{Stakeholder Connection in Tapak Village}

From the identification of stakeholder that involved in CBA, it found that the number of stakeholders that involved in CBA in Tapak Village is various. To support the adaptation activities, various stakeholder like NGO, Government, Academia and Private sector engage through giving financial support and advice/guidance.

Table 3 shows the connection between each stakeholder that involved in CBA. The degree shows the number of connections of specific stakeholder. Meanwhile in-degree shows the number of connections directed to the specific stakeholder and out-degree column shows the number of connections from specific stakeholder to others within the network. Referred from Table 3, the most number of connections are from and to Prenjak Group (community group) with the number of 19 in-degree and 17 out-degree. It implies from the result that Prenjak Group has the most connection within the network which also mean that Prejak Group has many accesses in the network.

In Tapak Village, the connection built in CBA is based on stakeholder interest in coastal management. Each stakeholder has their own goals in coastal conservation. Seeing from the city government side, there is no explicit program to support the CBA in Tapak. However, it can be seen that in RPJMD (Rencana Pembangunan Jangka Menengah Daerah - City Mid-term Development Planning Document) 2010-2015, in one of Semarang City mission which is Mewujudkan kemandirian dan daya saing daerah (achieving independence and competitiveness of the regions), DKP or marine and coastal agency becomes the leading institute for coastal community development to increase coastal productivity and coastal community environmental conservation. Meanwhile BLH or environmental board and Agriculture and Forestry Agency act in conducting coastal conservation through mangrove plantation which also supporting Semarang City mission in creating sustainable spatial and infrastructure. Thus the program created by government, for example, planting mangrove, always become the program that involving the community. To plant mangrove, the government only provide funding and community provide the seeds and responsible to plant the mangrove seeds.

City government agencies conduct the program by their own goals each in supporting city mission. For the coastal conservation, for instance in planting mangrove, city government agencies will often connect to a community group in implementation. Hence, for the implementation, they choose the community group based on their activeness in the forum. The involvement of Prenjak in KKMKS (Kelompok Kerja Mangrove Kota Semarang - Semarang Mangrove Working Group) is one of the factors that makes government agency includes Prenjak on their activity from 2011.

\section{Community Group Networking in Tapak}

In coastal management, the network is related to collaboration between stakeholders involved in coastal conservation. Community involvement in the city of Semarang activities related to coastal areas, for example, is represented by Prenjak Group in Tapak Village and the networking activity by Prenjak also bring them a wider network that can provide multiple benefits on their efforts in conserving the coastal areas. A community group can be seen as media in transferring knowledge to other community members (Feola \& Nunes, 2014; Nanlohy, Nur, \& Hutabarat, 2015) hence Prenjak group who has an advantage in having the highest degree in connection also become the most suitable place for community in Tapak to get information about climate change.

Figure 3 shows the network formed using the connection

Table 2. The Number of Stakeholder Involved In CBA In Tapak

\begin{tabular}{ccc}
\hline Type of Stakeholder & Role in CBA & Number of Stakeholders \\
\hline Community Group & Main actor, flow of information & 6 \\
NGO & funding, informal support/advice/guidance & 8 \\
Government & funding, informal support/advice/guidance & 3 \\
University & Flow of information, informal support/advice/guidance & 2 \\
Private Sector & funding & 1 \\
\hline
\end{tabular}

Source: Primary data 
Table 3. Number of Connection (degree) from Each Stakeholder

\begin{tabular}{|c|c|c|c|c|c|}
\hline Number & Stakeholder & Type & In-degree & Out-degree & Degree \\
\hline 1 & Prenjak Group & Community Group & 19 & 17 & 36 \\
\hline 2 & BINTARI & NGO & 15 & 16 & 31 \\
\hline 3 & $\begin{array}{l}\text { Dinas Kelautan dan Perikanan } \\
\text { (DKP) }\end{array}$ & Government & 11 & 13 & 24 \\
\hline 4 & Badan Lingkungan Hidup (BLH) & Government & 12 & 12 & 24 \\
\hline 5 & LPPM UNNES & University & 12 & 12 & 24 \\
\hline 6 & Diponegoro University & University & 11 & 12 & 23 \\
\hline 7 & Putri Tirang Group & Community Group & 13 & 8 & 21 \\
\hline 8 & Fishpond Farmer Group & Community Group & 9 & 10 & 19 \\
\hline 9 & Pokdarwis & Community Group & 13 & 6 & 19 \\
\hline 10 & Dinas Pertanian dan Kehutanan & Government & 7 & 11 & 18 \\
\hline 11 & Fishermen Group & Community Group & 8 & 10 & 18 \\
\hline 12 & Green Community & NGO & 9 & 7 & 16 \\
\hline 13 & KKMKS & NGO & 7 & 8 & 15 \\
\hline 14 & Community (Tapak) & Community Group & 10 & 5 & 15 \\
\hline 15 & MCI & NGO & 6 & 7 & 13 \\
\hline 16 & KeSeMat & NGO & 3 & 4 & 7 \\
\hline 17 & FoE & NGO & 1 & 5 & 6 \\
\hline 18 & PERDIKAN & NGO & 1 & 3 & 4 \\
\hline 19 & BKM & Community Group & 2 & 2 & 4 \\
\hline 20 & Marimas & Private Sector & 1 & 1 & 2 \\
\hline
\end{tabular}

Source: Processed Primary Data

from each stakeholder in CBA. It can be inferred from Figure 3 that Prenjak has the most connection among other stakeholders in CBA in Tapak village shows by the number or arrow from and to Prenjak Group. From the Prenjak Group network that can be seen in Figure 3, Prenjak group has the most direct connection with all type of stakeholder. Figure 3 shows the in-degree which refers that Prenjak group received attention from other stakeholders in CBA. The form of attention that they received are in term of funding to conduct the activity, capacity building/advice/guiding, and flow of information. Among community group in Tapak, there is only Prenjak Group which has a direct connection with the private sector to access funding from the private sector through Corporate Social Responsibility (CSR) program.

Another stakeholder that has a significant connection in the network of stakeholder in Tapak is Bintari, DKP, BLH, and UNNES. Figure 2 describes the connection of four important stakeholders in Tapak Village CBA which are BINTARI, DKP, BLH, and LPPM UNNES. From the perspective of those other stakeholders, Prenjak still has the highest number of degrees shows with the biggest node in Figure 4. According to Nanlohy H., Nur, A., \& Hutabarat S,
(2015) community group is important as a media in learning by and to the community. If seeing from the interest of each stakeholder to Prenjak, they also tend to increase community capacity through many activities such as planting mangrove. However, they cannot directly be connected to the community, therefore they connected to Prenjak in order to give capacity to Prenjak so they can transfer the skills to communities in Tapak Village.

Can be seen in Figure 4, BINTARI and LPPM Unnes have the most significant number of communities group that connected to them. Both BINTARI and LPPM Unnes are stakeholders that give assistance to communities in term of community development. Both stakeholders considered as an important stakeholder in the network because of their connection not only to capacitate community but also has a connection with funding. As can be seen in Figure 3, that Prenjak Group is still having the biggest degree among others from the perspective of the network from Bintari, DKP, BLH, and LPPM UNNES. Among them, it also can be seen that those stakeholders are also having connection to each other. It is also mean that within the network, each important stakeholder are connected and it should broaden the chance to optimizing the connection through various activities 
Figure 3. Prenjak Group Connection in CBA Stakeholder Network

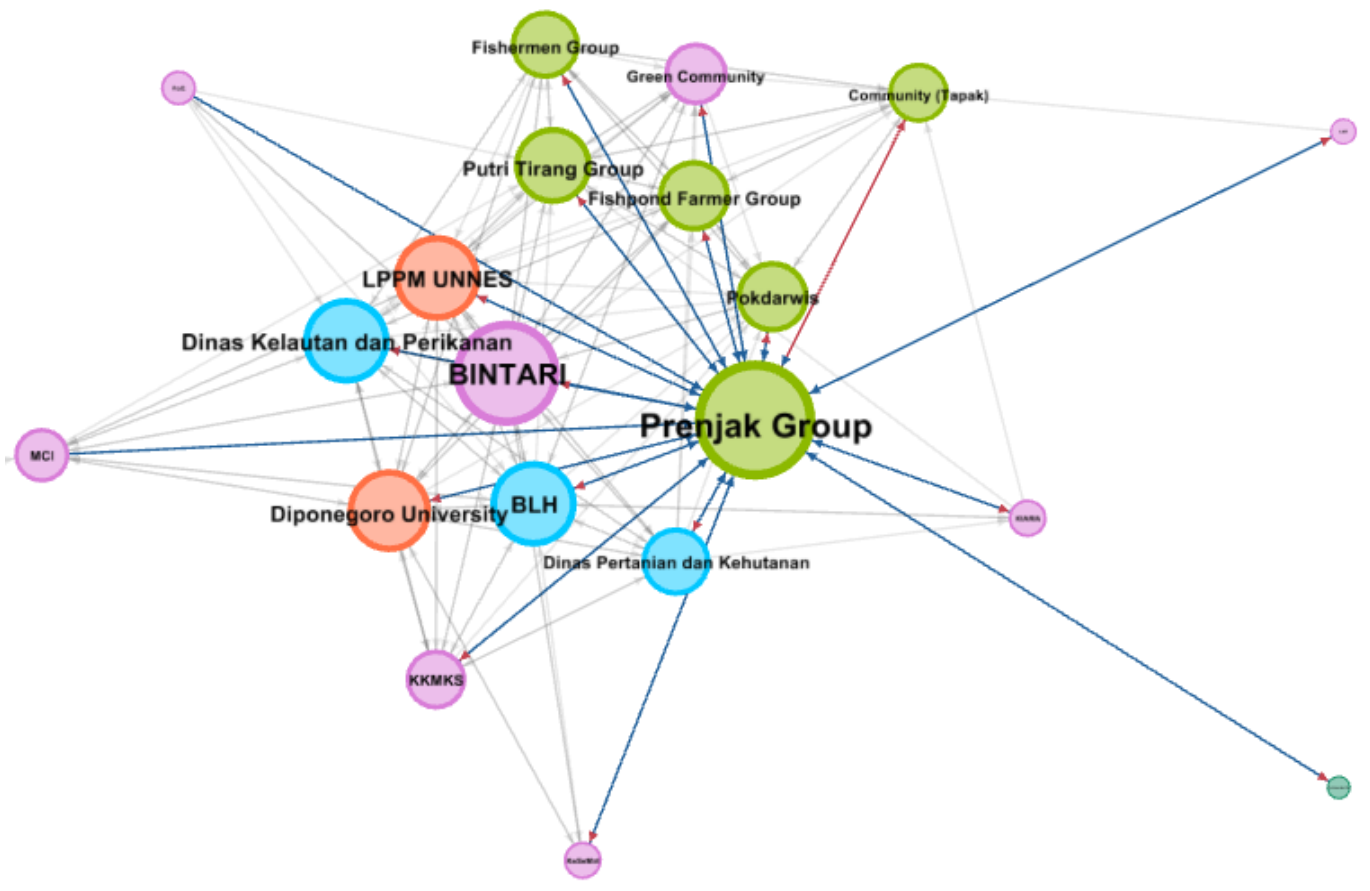

(a)

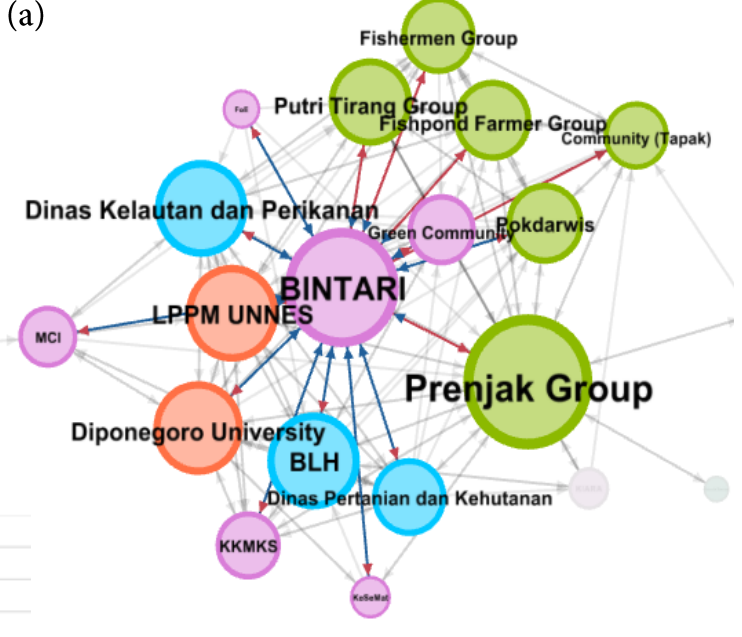

(c)

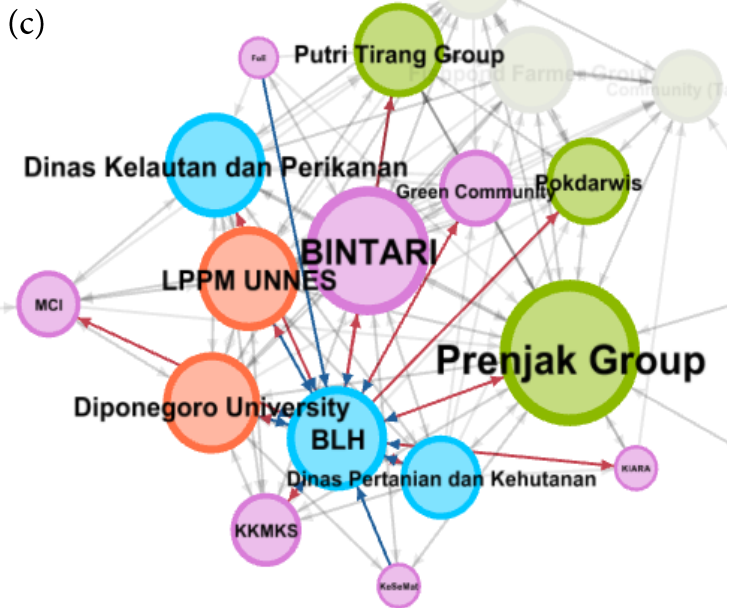

(b)

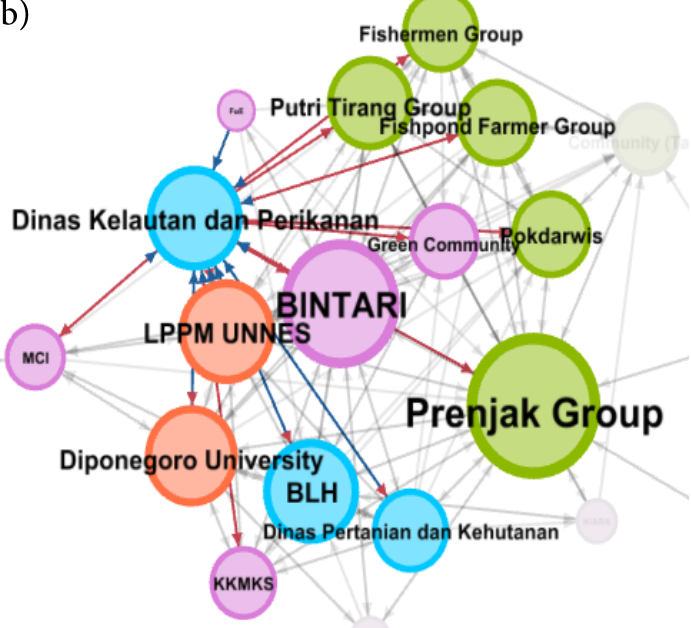

(d)

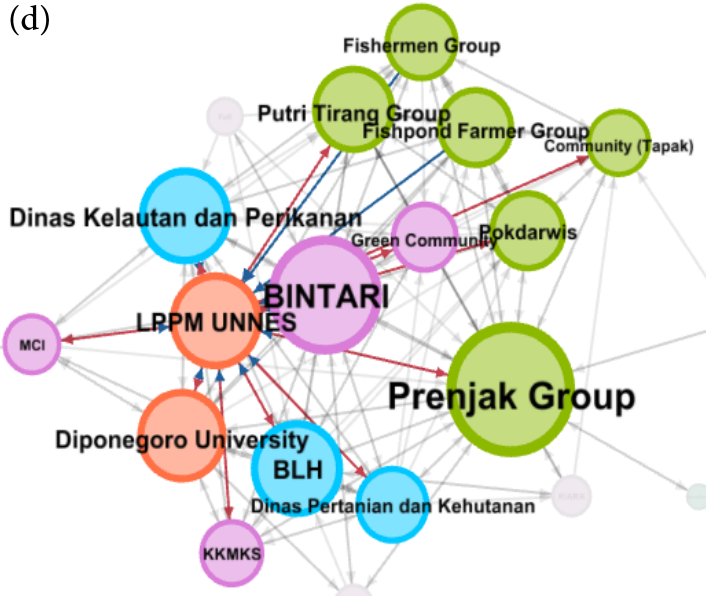

Figure 4. (a) Bintari Connection in CBA Stakeholder Network, (b) DKP Connection in CBA Stakeholder Network, (c) BLH connection in CBA stakeholder network, (d) LPPM UNNES connection in CBA stakeholder network 
Table 4. Stakeholder Rank Based on the Betweenness Centrality

\begin{tabular}{ccccc}
\hline Number & Stakeholder & Type & Closeness Centrality & Betweenness Centrality \\
\hline 1 & Prenjak Group & Community Group & 1.11 & 119.27 \\
2 & MCI & NGO & 1.63 & 57.11 \\
3 & BINTARI & NGO & 1.16 & 50.29 \\
4 & KKMKS & NGO & 1.58 & 0.00 \\
\hline
\end{tabular}

Source: Processed Primary Data

involving community in Tapak as well as to disseminate the CBA effort from Tapak.

The betweenness centrality in Table 4 shows how often the stakeholder has the shortest connection to the other. The higher number of betweenness centrality of stakeholder means that the stakeholder has a higher influence in connecting with other stakeholders. This means that the existence of this particular stakeholder will affect the connection on the network. From the degree of closeness centrality and betweenness centrality, we can see that Prenjak Group has the highest level of betweenness centrality.

Prenjak become the bridge of connection between communities to other stakeholders because Prenjak has access to both outside stakeholder and community member in Tapak Village. Prenjak has a lot of advantages with the position as having the highest degree of betweenness centrality in the network because Prenjak is the stakeholder that has the most connection to other stakeholders in sustaining their CBA effort. The low value of closeness to centrality means that Prenjak can have access to other stakeholders in the network because of their connection to the stakeholder. Prenjak can have access information even with the source of funding.

The closeness centrality degree in Table 4 shows the average distance from stakeholder to the other which mean the lower number of this degree shows the closer this stakeholder to the other stakeholder in the network. Without the existence of Prenjak Group, the other community groups cannot have access to the network such as funding from the private sector and capacity building.

Kelompok Kerja Mangrove Kota Semarang (KKMKS) Semarang Mangrove Working Group

Stakeholder with zero betweenness centrality (Private Sector, LBH, KeSeMat, FoE, KKMKS) means that their existence in the network does not effects the connection between stakeholders. Refers to the degree that they have in Table 3, those stakeholders have the lowest number of indegree and out-degree which also mean they have the lowest connection among stakeholders in the network. Although KKMKS seems to have the average number of degree, their existence does not significantly affect the network.

Initial formation of KKMKS begins as a response to the Presidential Regulation No. 73 the year of 2012 on the National Strategy for Mangrove Ecosystem Management which stated the needs of coastal areas in Indonesia to forms across sectors/agencies/NGOs working team concerning in mangrove conservation. In Semarang, the formation of

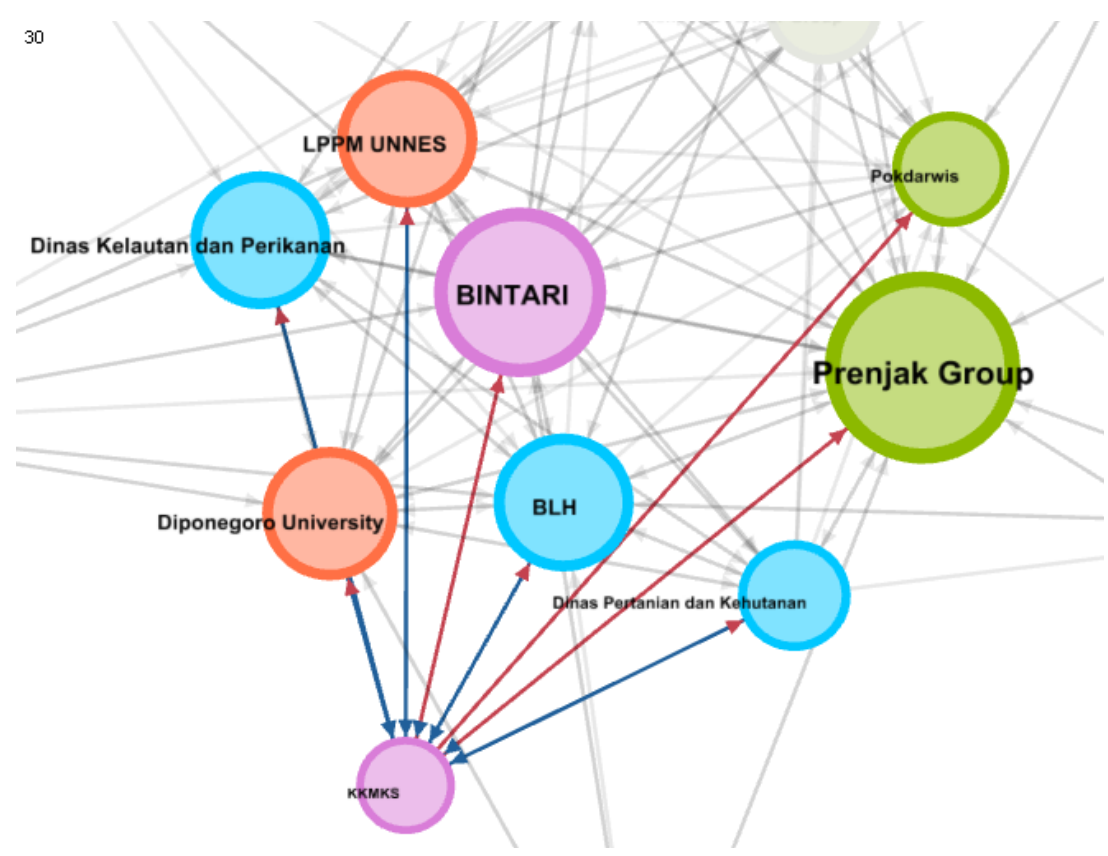

Figure 5. KKMKS Network in CBA Stakeholder Network 
KKMKS aims to bridge all the stakeholders in the management of mangrove in Semarang in order to establish better coordination to save mangroves in the coastal area of Semarang and surrounding areas that have been damaged up to $90 \%$. The member of KKMKS including government, NGO, academia, and community group.

KKMKS has 15 degrees with total 8 in-degree and 7 outdegree number. It has a higher in-degree number than the out-degree number which is mean that KKMKS become the target for connection. Not only increasing mangrove density in the coastal area, KKMKS also giving chances of the members to share knowledge through KKMKS regular meetings at least once a month to discuss the progress of the conservation of mangroves in the coastal area of Semarang. Many institutions as KKMKS members attend monthly meetings and share information on mangrove and coastal development and expand their networks through meetings. Thus the condition is reflected in the interview that KKMKS can become the forum for the flow of information among stakeholder in the network. In addition, through their network in KKMKS, Prenjak managed to obtain funds to plant mangroves in their area.

\section{Conclusion}

Coastal region is the meeting point between the sea and land. Based on Indonesia law number 27 year of 2007, coastal region is stated as the transition of the sea and land which related with the changes is land and sea. In fact, as an archipelago country, Indonesian coastal areas are the most dynamic and strategic areas for development as they provide many resources for human livelihood. On the other hand, the coastal area also prone to the hazard such as erosion and sedimentation process (Marfai, 2011).

As bottom-up approach, CBA can recognizes the importance of local context and other actors, particularly those at the level in which adaptation is operationalized, in formulating and implementing policies (Fenton, Gallagher, Wright, Huq, \& Nyandiga, 2014). The presence of Prenjak Group is essential in the networking process of CBA in Tapak. Community group can be seen as media in transferring knowledge to community member (Feola \& Nunes, 2014; Nanlohy et al., 2015) hence Prenjak as the most stakeholder who has advantage in having highest degree in connection (see Table 3 and Table 4) also become the most suitable place for community in Tapak to get information about climate change. Besides, broaden the network resulting the increase of chance in getting capacity building for the community group. What makes it different in Tapak Village is because the position of Prenjak in the CBA stakeholder network in Tapak is more strategic to build a relationship with both internal stakeholder (other community groups in their area) and external stakeholder (stakeholder that not present in the area). This is because Prenjak has the most connection to the other stakeholders.

The networking in CBA not only performed by the group of community within the network. Although CBA is a local approach, the sustainability of this process is depend on the engagement of various stakeholder including government, private sector, academia and NGO (Feola \& Nunes, 2014; King, 2014). Learning from CBA in Tapak, the person of Prenjak that involves in KKMKS is always the leader that comes to KKMKS activities. Hence, they represent Prenjak as a group in the KKMKS activities. However, personal interaction between members in Prenjak to other members in the institute within the network of CBA in Semarang are counted as the informal connection that can increase the chance of wider networking in the future. For instance, one of Prenjak member also are members of Pokdarwis group (community group) plus that member is family the person in Putri Tirang group (community group). So the connection is more informal or within a family member in the network, although they do not represent the group, the interactions are matter in broader the network between community groups.

The involvement of Prenjak in KKMKS brings the opportunity through accessing the wider network. The existence of a community group in a forum like KKMKS is needed because it gives an opportunity for a community group to not only develop their skills through networking but also given a chance for any assistance or guidance opportunities.

Community in Tapak also has the trust that community group can help with the Rob (tidal inundation) issues in their areas. Which mean that they believe that being together as a group will make them become more powerful to help with the Rob problem. The presence of a community group in Tapak is also essential in delivering knowledge to their community. Prenjak group has been the leader of their community in introducing conservation action in their coastal area and become the center of knowledge by the flow of information that they can access through the network.

As mentioned before, Prenjak networking can be considered as the factor that greatly influences their sustainability. Prenjak as the focal point of the stakeholder network means that the presence of Prenjak is essential in the networking process of CBA in Tapak. The participation of community is essential in the long-term achievement of sustainability (Marfai, 2011). KKMKS as the forum for Prenjak to access more network also has been proved to bring positive impact to the sustainability of CBA process in Tapak. In this case, community group participation such as Prenjak participation and their networking among CBA stakeholder can be considered as the lesson for the CBA especially in the term of maintaining their sustainability. CBA is an approach that focused on empowering people so that they can be more resilient to the changes. CBA can be risen from inside the community or triggered by outsider for example activities from NGO (Non-government Organization) or government. It is increasingly recognized as a key way for the world's poorest and most vulnerable people to build capacity to cope with the impacts of climate change (Ayers \& Huq, 2009). Generating adaptation strategies with communities and other local stakeholders increase the chance for sustainability of the process (Feola \& Nunes, 2014) because communities develop a strong sense of ownership and their priorities are met (Feola \& Nunes, 2014; King, 2014). By maintaining the network that Prenjak already had in the CBA process, it can also maintain the sustainability of their effort in the future. However, further research is needed in identifying the type of networking applies to sustain the CBA effort considering the formal and informal networking by the community group or community leader.

Acknowledgment 
The authors would like to send the words of gratitude to the Vocational School, Diponegoro University for funded this research publication. We thank also for the survey participants for their participation and responses. All the contents of this paper are solely responsibility of the authors.

\section{References}

Archer, D., Almansi, F., DiGregorio, M., Roberts, D., Sharma, D., \& Syam, D. (2014). Moving towards inclusive urban adaptation: approaches to integrating community-based adaptation to climate change at city and national scale. Climate and Development, (June), 1-12. https:// doi.org/10.1080/17565529.2014.918868

Ayers, J., \& Huq, S. (2009). Community-Based Adaptation to Climate Change: An update. IIED Briefing, (June). Retrieved from http://www.iied.org/pubs/pdfs/17064IIED.pdf

Buchori, I., Pramitasari, A., Sugiri, A., Maryono, M., \& Basuki, Y. (2018). Adaptation to coastal $\mathrm{fl}$ ooding and inundation邓: Mitigations and migration pattern in Semarang City, Indonesia. Ocean and Coastal Management, 163(July), 445455. https://doi.org/10.1016/j.ocecoaman.2018.07.017

Bintari Foundation. (2016). Upaya Adaptasi Dampak Perubahan Iklim Sektor Pesisir di Tapak Tugurejo Semarang. Semarang: BINTARI Foundation

Buchori, I., Sugiri, A., Mussadun, M., Wadley, D., Liu, Y., Pramitasari, A., \& Pamungkas, I. T. D. (2018). A predictive model to assess spatial planning in addressing hydrometeorological hazards: A case study of Semarang City, Indonesia. International Journal of Disaster Risk Reduction, 27(October), 415-426. https://doi.org/10.1016/ j.ijdrr.2017.11.003

Carter, J. G., Cavan, G., Connelly, A., Guy, S., Handley, J., \& Kazmierczak, A. (2014). Climate change and the city: Building capacity for urban adaptation. Progress in Planning, 95, 1-66. doi:10.1016/j.progress.2013.08.001

Fenton, A., Gallagher, D., Wright, H., Huq, S., \& Nyandiga, C. (2014). Up-scaling finance for community-based adaptation. Climate and Development, 6(December), 388-397. https:// doi.org/10.1080/17565529.2014.953902

Feola, G., \& Nunes, R. (2014). Success and failure of grassroots innovations for addressing climate change: The case of the transition movement. Global Environmental Change, 24, 232-250. https://doi.org/10.1016/j.gloenvcha.2013.11.011

Handayani, W., \& Kumalasari, N. R. (2015). Migration as Future
Adaptive Capacity: The Case of Java-Indonesia. Environmental Change, Adaptation and Migration: Bringing in the Region, 117-138. https:// doi.org/10.1057/9781137538918_7

Kate, L., Keener, V., Finucane, M., Brewington, L., \& Nunncrichton, R. (2015). Psychosocial Intervention. Psychosocial Intervention, 24(3), 133-146. https://doi.org/10.1016/ j.psi.2015.07.004

King, S. (2014). Community-based adaptation: A global overview of CARE International's practice of Community-Based Adaptation (CBA) to climate change. 62pp.

Marfai, M. A. (2011). The hazards of coastal erosion in Central Java , Indonesia囚: An overview. Geografia, 3(3), 1-9.

Marfai, M. A., \& King, L. (2008a). Coastal flood management in Semarang, Indonesia. Environmental Geology, 55, 15071518. https://doi.org/10.1007/s00254-007-1101-3

Marfai, M. A., \& King, L. (2008b). Tidal inundation mapping under enhanced land subsidence in Semarang, Central Java Indonesia. Natural Hazards, 44, 93-109. https:// doi.org/10.1007/s11069-007-9144-Z

Marfai, M. A., King, L., Sartohadi, J., Sudrajat, S., Budiani, S. R., \& Yulianto, F. (2008). The impact of tidal flooding on a coastal community in Semarang, Indonesia. Environmentalist, 28, 237-248. https://doi.org/10.1007/s10669-007-9134-4

Marshall, N. A., Park, S., Howden, S. M., Dowd, A. B., \& Jakku, E. S. (2013). Climate change awareness is associated with enhanced adaptive capacity. Agricultural Systems, 117, 3034. https://doi.org/10.1016/j.agsy.2013.01.003

Nanlohy, H., Nur, A., \& Hutabarat, S. (2015). Coastal Communities Knowledge Level on Climate Change As a Consideration in Mangrove Ecosystems Management in the Kotania Bay, West Seram Regency. Procedia Environmental Sciences, 23 (Ictcred 2014), 157-163. https://doi.org/10.1016/ j.proenv.2015.01.024

Presidential Regulation. (2012). Presidential Regulation No. 73 the year of 2012 on the National Strategy for Mangrove Ecosystem Management. Indonesia.

Scott, John. (2000). Social Network Analysis: A Handbook. SAGE Publication.

Semarang Center of Statistical Bureau. (2018). Kecamatan Tugurejo dalam Angka 2017. Semarang. 